\title{
Development of a real-time quantitative PCR assay using a TaqMan minor groove binder probe for the detection of $\alpha$-lactalbumin in food
}

\author{
Guan Xiao, Cai Qin, Zhang Wenju, and Chen Qin ${ }^{1}$ \\ School of Life Science, Shanghai University, Shanghai 200444, China
}

\begin{abstract}
Here, we report the development of a real-time PCR assay using a TaqMan minor groove binder (MGB, Genecore, NCBI: AF249896.1, 806-820) probe and primer sets designed to recognize the $\alpha$-lactalbumin gene from the cow (Bos taurus). We evaluated the efficacy of this assay for detecting and quantifying cow $\alpha$-lactalbumin in commercial foods. Our results demonstrated that the developed method was highly sensitive and showed high specificity for cow milk, with consistent detection of $0.05 \mathrm{ng}$ of bovine DNA. We tested 42 commercial food samples with or without cow milk listed as an ingredient by using the developed assay. Among the 42 samples, 26 products that listed milk as an ingredient and 3 products might contain milk showed positive signals, whereas the other 9 products that did not contain milk and 4 products that might contain milk tested negative. Therefore, this method could be widely used for the detection of cow milk allergens in food.
\end{abstract}

Key words: milk allergen, $\alpha$-lactalbumin, TaqMan minor groove binder, real-time PCR

\section{INTRODUCTION}

Milk is one of the most common food allergens for infants and young children, with an incidence of approximately 2 to $3 \%$ in the general population (Bock, 1987; Høst and Halken, 1990; Schrander et al., 1993; Saarinen et al., 2005; Pan et al., 2013). Milk allergies can cause severe adverse reactions, including digestive problems and respiratory disorders such as asthma. Many of these reactions lack general treatment options and can only be prevented by avoiding contact with allergens (Businco et al., 1995; Boyce et al., 2011). To help prevent contact, labeling of food products that

Received August 14, 2015.

Accepted November 11, 2015.

${ }^{1}$ Corresponding author: chenqincc@staff.shu.edu.cn contain milk allergens is mandatory (Eissa et al., 2012). However, many allergic reactions still occur when the presence of milk allergens is not indicated on food packaging. Therefore, to protect the health of consumers, it is imperative to establish a simple, feasible method for the detection of milk allergens in food.

Enzyme-linked immunosorbent assay and PCR are most commonly used methods for the detection of food allergens (Stephan and Vieths, 2004; Rodriguez-Lazaro and Hernandez, 2013; Rodriguez-Lazaro et al., 2013). Recently, more novel methods were developed for food allergens detections such as chromatography, mass spectrometry, and magnetoimmunosensing (Posada-Ayala et al., 2015; Ruiz-Valdepeñas Montiel et al., 2015). An ELISA is an immunoassay method that is frequently used to detect allergens in food (Koch et al., 2003; López-Calleja et al., 2013). To determine whether food items contained milk allergens, Docena et al. (2002) used both ELISA and immunoblotting to detect the milk protein casein. To improve the speed of detection, Song et al. (2014) developed an immunomagnetic bead ELISA to detect $\beta-\mathrm{CN}$ in cow milk. Compared with a classical sandwich ELISA, this method significantly shortened the time required for detection. However, ELISA-based detection has been shown to be unreliable because proteins can be easily denatured during food processing, especially when exposed to high temperature or pressure (Johnson et al., 2010). For example, Wijesinha-Bettoni et al. (2007) reported that monomeric, dimeric, and oligomeric forms of $\alpha$-LA are present after $120 \mathrm{~min}$ of heating. In addition, the presence of other biomolecules (e.g., lipids and sugars) in milkcontaining products, such as biscuits and chocolate, might interfere with the ELISA results (Khuda et al., 2012; Qing-jin et al., 2012). Furthermore, the efficacy of each immunoassay depends on the activity of the specific antibody used, and antibody cross-reactivity can often lead to false-positive results (Scaravelli et al., 2009). As DNA molecules are more stable than proteins and can withstand the harsher treatments used during food processing, the current study aimed to develop a real-time PCR-based assay involving a TaqMan minor groove binder (MGB, Genecore, NCBI: AF249896.1, 
806-820) for the detection of the Bos taurus (dairy cow) $\alpha$-LA gene and to use the developed assay to detect milk in food products.

\section{MATERIALS AND METHODS}

\section{Materials}

Milk from the domestic dairy cow (Bos taurus) and goat (Capra hircus), as well as soybean (Glycine max) milk, peanuts (Arachis hypogaea), hazelnuts (Corylus heterophylla), Atlantic salmon (Salmo salar), and various commercial food products were purchased from a local supermarket. The peanuts, hazelnuts, Atlantic salmon, 6 kinds of candies, 17 kinds of biscuits, and 7 kinds of chocolates were ground in preparation for DNA extraction and then stored at $4^{\circ} \mathrm{C}$. Liquid samples, including cow milk, goat milk, soybean milk, and 12 kinds of other drinks, were directly used for DNA extraction without any pretreatment.

\section{DNA Extraction}

The DNA from the milk samples (cow milk, goat milk, and soybean milk) was extracted as described by Xian et al. (2008). First, $100 \mathrm{~mL}$ of liquid was centrifuged at $2,100 \times g$ for $10 \mathrm{~min}$ at $4^{\circ} \mathrm{C}$. After decanting the supernatant, the fat that had adhered to the inner side of the centrifuge tube was removed with alcohol-soaked cotton, and then the sediment was resuspended in 880 $\mu \mathrm{L}$ of TEN (10 $\mathrm{m} M$ Tris, $1 \mathrm{~m} M$ EDTA, $100 \mathrm{~m} M \mathrm{NaCl}$ ) and $120 \mu \mathrm{L}$ of $200 \mathrm{mM} \mathrm{NaOH}$ and incubated at $95^{\circ} \mathrm{C}$ for $8 \mathrm{~min}$. After incubation, the samples were centrifuged at 2,100 $\times g$ for $10 \mathrm{~min}$ at $4^{\circ} \mathrm{C}$. The supernatant was transferred to a new 5 -mL capped centrifuge tube, mixed with an equal volume of phenol-chloroformisoamyl alcohol (25:24:1), vortexed, and centrifuged at $2,100 \times g$ for 15 min at $4^{\circ} \mathrm{C}$. The upper aqueous phase was transferred to a new 2-mL tube and mixed with an equal volume of chloroform-isoamyl alcohol (24:1). After centrifugation at $2,100 \times g$ for $10 \mathrm{~min}$ at $4^{\circ} \mathrm{C}$, the sediment was washed with $70 \%$ ethanol, air-dried, and then dissolved in $50 \mu \mathrm{L}$ of TE solution ( $2 \mathrm{~m} M$ Tris, 0.2 $\mathrm{m} M$ EDTA).

Genomic DNA from the candies, biscuits, chocolates, and drinks was extracted using the cetyltrimethylammonium bromide method (Reguant and Bordons, 2003; Zhang et al., 2015). The DNA concentration was measured by UV absorption spectrophotometry (Colibri, Pforzheim, Germany) at a wavelength of $260 \mathrm{~nm}$. All the chemicals were provided by SCRC (Shanghai, China).

\section{Oligonucleotide Probe and Primers}

Using Primer Express 3.0 (Applied Biosystems, Thermo Fisher Scientific, Waltham, MA), a set of primers and a probe were designed for use in real-time PCR amplification based on the DNA sequence of the bovine (Bos taurus) $\alpha$-LA gene (NCBI AF249896.1). The sequences of the oligonucleotides synthesized were as follows: Forward primer: F1 (22 bp, 5'-CACCCAG GCTGAACAGTTAACA-3'); reverse primer: R1 (22 bp, 5'-TCCGTAGCCCTTCAAGTCTTTC-3'); and MGB probe: P1 (15 bp, FAM-AGGTGTTCCG GGAGC-MGB). The amplicon sequence for TaqMan MGB was as follows: 797-CACCCAGGCTGAACAGT TAACAAAATGTGAGGTGTTCCGGGAGCTGAAA GACTTGAAGGGCTACGGA-864.

\section{TaqMan MGB Real-Time PCR Conditions}

The reaction mixtures contained $2 \mu \mathrm{L}$ of DNA template, $10 \mu \mathrm{L}$ of real-time PCR Master Mix (Toyobo, Osaka, Japan), $0.4 \mu M$ probe, $0.2 \mu M$ each primer (forward and reverse), and molecular biology grade water (Takara, Shiga, Japan) in a final volume of 20 $\mu \mathrm{L}$. The thermal cycling program was an initial DNA denaturation step at $95^{\circ} \mathrm{C}$ for $10 \mathrm{~min}$, followed by 40 cycles of DNA denaturation at $95^{\circ} \mathrm{C}$ for $15 \mathrm{~s}$, annealing at $59^{\circ} \mathrm{C}$ for $30 \mathrm{~s}$, and elongation at $72^{\circ} \mathrm{C}$ for $30 \mathrm{~s}$. Amplicon production was measured during the annealing and elongation steps of each cycle. All reactions were run in a CFX96 Touch system (Bio-Rad, Hercules, CA). Three independent replicates were used for each reaction, and the data are presented as the mean cycle threshold (Ct) values and standard deviations. For each 96-well plate, 3 reactions without templates and 3 positive samples were used as the negative and positive controls, respectively.

\section{Annealing Temperature and Probe Concentration}

We tested the effect of different annealing temperatures $\left(55.0,55.7,57.0,59.0,61.4,63.3,64.5\right.$, and $\left.65.0^{\circ} \mathrm{C}\right)$ and different probe concentrations $(0.1,0.2,0.3,0.4$, and $0.5 \mu M)$. All other PCR conditions were the same as described above.

\section{Specificity}

The specificity of the real-time PCR assay for cow milk was determined by testing DNA extracts from goat milk, soybean milk, peanuts, hazelnuts, and At- 
lantic salmon. The extracts were used as templates in the real-time PCR assay described above. Each sample was tested in triplicate, using $2 \mu \mathrm{L}$ of each DNA extract $(15 \mathrm{ng} / \mu \mathrm{L})$ as a template.

\section{Sensitivity, Standard Curve Generation, and Amplification Efficiency}

To determine the detection $\mathrm{Ct}$ of the assay, bovine genomic DNA samples were serially diluted 10-fold $(25,2.5,0.25,0.025,0.0025$, and $0.00025 \mathrm{ng} / \mu \mathrm{L})$ and $2 \mu \mathrm{L}$ of each dilution was used as the template in the real-time PCR assay. Standard curves were generated using the $\mathrm{Ct}$ values obtained, and then the slope of the standard curve, standard deviations, and amplification efficiency were calculated.

\section{Comparison of PCR Methods}

To compare the specificity and sensitivity of our TaqMan MGB real-time PCR assay with another method, we also performed SYBR Green (Toyobo) real-time PCR using the same templates. A second set of primers was designed using Primer Premier 5.0 (Premier Biosoft International, Palo Alto, CA) based on the DNA sequence of bovine $\alpha-\mathrm{LA}$. The primer sequences were as follows: Forward primer, F2 (20 bp, 5'- GTGGTATT GGTGGTTGGGGA-3'), and reverse primer, R2 (20 bp, 5'- TGGTTCCTTGTTGAGTGGTCA-3'). The amplicon sequence for TaqMan MGB was as follows: 60-GTGGTATTGGTGGTTGGGGATGGGGAGGCT GATAGCATCTCAGAGGGCAGCTAGATACTGTCA TACACACTTTTCAAGTTCTCCATTTTTGTGAA ATAGAAAGTCTCTGGATCTAAGTTATATGTGAT TCTCAGTCTCTGTGGTCATATTCTATTTCTACT CCTGACCACTCAACAAGGAACCA-243.

The SYBR Green real-time PCR mixtures contained $2 \mu \mathrm{L}$ of DNA template, $10 \mu \mathrm{L}$ of $2 \times$ SYBR Green realtime PCR Master Mix (Toyobo), $0.15 \mu M$ each primer (forward and reverse), and double distilled water in a final volume of $20 \mu \mathrm{L}$. Amplifications were carried out in a CFX96 Touch system (Bio-Rad), using an initial denaturation step at $95^{\circ} \mathrm{C}$ for $30 \mathrm{~s}$, followed by 40 cycles of denaturation at $95^{\circ} \mathrm{C}$ for $10 \mathrm{~s}$, annealing at $56^{\circ} \mathrm{C}$ for $15 \mathrm{~s}$, and extension at $72^{\circ} \mathrm{C}$ for $25 \mathrm{~s}$. Amplicon production was measured during the annealing and elongation steps of each cycle.

The specificity of the real-time PCR reactions for cow milk was determined by testing DNA extracts from goat milk, soybean milk, peanuts, hazelnuts, and Atlantic salmon. In addition, various amounts of DNA template $(50,5,0.5,0.05$, and $0.005 \mathrm{ng})$ were used in the PCR reactions to test the sensitivity of the SYBR Green real-time PCR.

\section{Validation of TaqMan MGB Real-Time PCR}

The DNA extracts from 42 commercial food items were tested by using the real-time PCR method described above. Then, the test results were compared with the declarations of ingredients on the food labels to determine the reliability of the method.

\section{RESULTS}

\section{Determination of the Optimal Annealing Temperature}

To optimize the method, the TaqMan MGB real-time PCR was carried out using a bovine-specific probe and primer sets and with various annealing temperatures. The amplification curves obtained are shown in Figure 1. Signals were detected in all reactions; however, the specific Ct values and relative fluorescent units (RFU) varied. The highest RFU and lowest $\mathrm{Ct}$ values were obtained when an annealing temperature of $59^{\circ} \mathrm{C}$ was used. Therefore, this annealing temperature was used for all subsequent reactions.

\section{Determination of the Optimal Probe Concentration}

We performed the PCR with various concentrations of probe. Although we did not detect a difference in the amplification obtained with the different concentrations of the probe (amplification curves not shown), the $\mathrm{Ct}$ values calculated from the amplification curves were lowest at a probe concentration of $0.4 \mu M$. Therefore, we used this concentration for all subsequent reactions.

\section{Specificity}

To assess the specificity of the reaction for bovine DNA, we extracted DNA from cow milk, goat milk, and soybean milk as well as other allergens (peanut, hazelnut, and Atlantic salmon) commonly found in commercial food products. We used these samples as templates for our TaqMan MGB real-time PCR assay. The results of these experiments demonstrate the specificity of the assay (Figure 2). We obtained a positive signal when DNA from cow milk was used as the template, whereas no such signal was observed when DNA from the other samples was used as the template. These results demonstrate that the probe and primer set used 


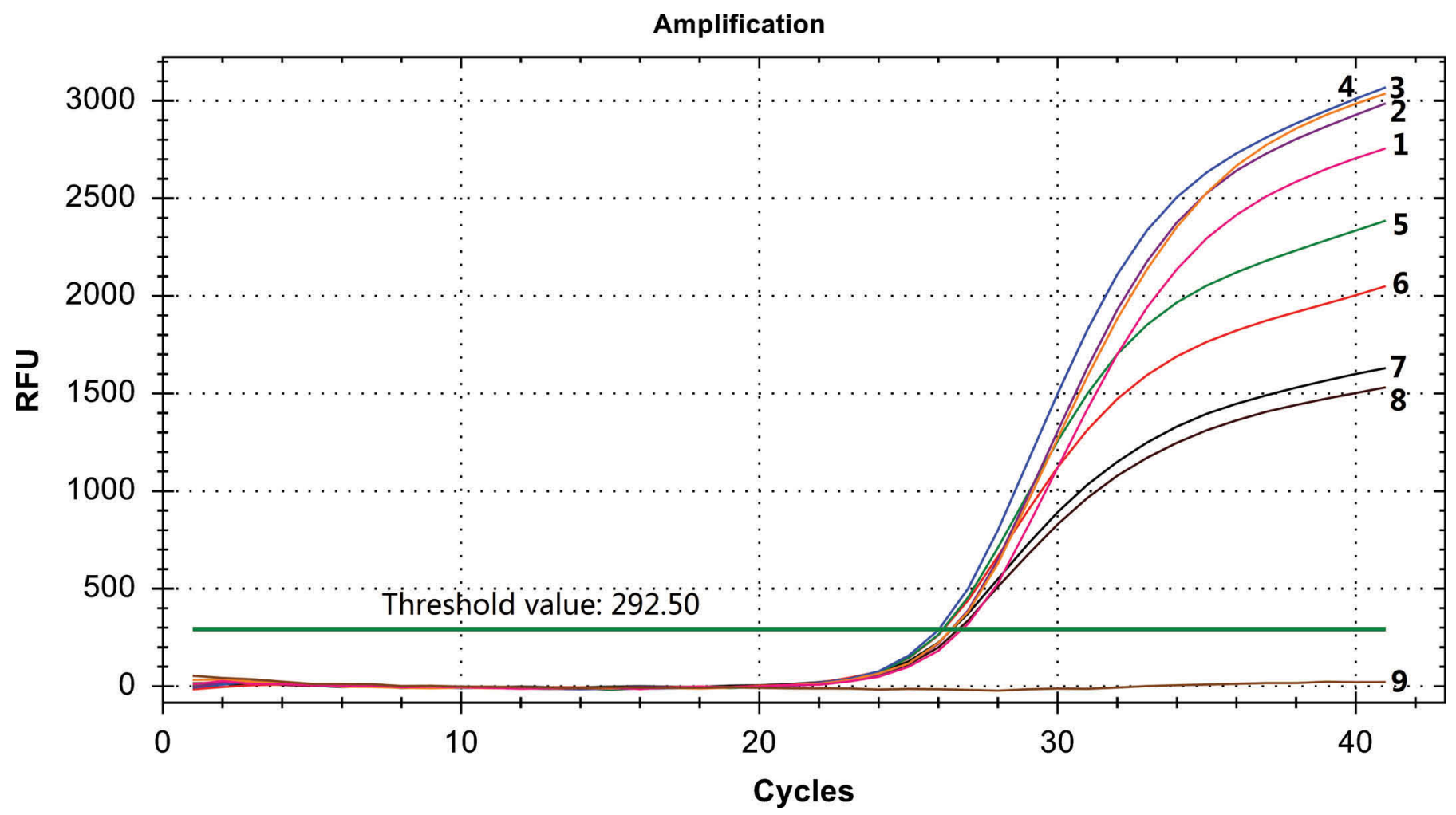

Figure 1. Effect of annealing temperature on TaqMan minor groove binder (Genecore, NCBI: AF249896.1, 806-820) real-time PCR. Curves 1-8: $55.0,55.7,57.0,59.0,61.4,63.3,64.5$, and $65.0^{\circ} \mathrm{C}$, respectively; curve $9=$ negative control. $\mathrm{RFU}=$ relative fluorescence units. Color version available online.

in our reaction mixture allowed for specific detection of cow milk, with no amplification of DNA from other tested species.

\section{Sensitivity}

To determine the sensitivity of the TaqMan MGB real-time PCR assay, we prepared 10-fold serial dilutions of bovine DNA isolated from cow milk and used it as the template (6 different amounts: 50, 5, 0.5, 0.05, 0.005 , and $0.0005 \mathrm{ng}$ ) in the reaction. The fluorescence profiles of the PCR products showed that a signal could be detected in reactions with as little as $0.005 \mathrm{ng}$ of DNA (Figure 3). However, although we were occasionally able to detect a signal using $0.005 \mathrm{ng}$ of DNA within 40 amplification cycles, detection was inconsistent at this concentration, and among the 3 replicates, only 1 positive result was obtained. Therefore, we concluded that the lower limit for the reliable detection of $\alpha-\mathrm{LA}$ from cow milk DNA is $0.05 \mathrm{ng}$.

\section{Standard Curve Generation and Amplification Efficiency}

To test the linearity of the TaqMan MGB real-time PCR amplification, the normalized $\mathrm{Ct}$ values were plotted against the logarithm of the template DNA concentrations. Linearity was observed over 5 orders of magnitude. Using the $\mathrm{Ct}$ values from each 10 -fold dilution, the equation for the generated standard curve was $\mathrm{y}=-3.673 \mathrm{x}+31.496$. The amplification efficiency was $85.7 \%$, with a coefficient of determination value of 0.998 . This value of 0.998 indicates that $99.8 \%$ of the variation in the $\mathrm{Ct}$ values is due to variations in the concentration of cow milk DNA.

\section{Comparison of PCR Methods}

To compare the specificity and sensitivity of TaqMan MGB real-time PCR and SYBR Green real-time PCR, we also tested the DNA we prepared from 6 food samples (cow milk, goat milk, soybean milk, peanuts, hazelnuts, and Atlantic salmon) using SYBR Green real-time PCR (Figure 4). The amplification curves for cow milk (curve 1) and goat milk (curve 2) had similar melting temperatures, which indicated that the SYBR Green method cannot distinguish between cow milk and goat milk, whereas the TaqMan MGB real-time PCR assay could distinguish these 2 samples, indicating better specificity. The amplification curve of soybean milk (curve 3) showed negative signals, and peanuts, hazelnuts, and Atlantic salmon did not show up in the figure 
because of their low amplification signals. In addition, in a sensitivity experiment using 5 different amounts of purified DNA from cow milk $(50,5,0.5,0.05$, and $0.005 \mathrm{ng}$ ), we detected as little as $0.5 \mathrm{ng}$ of bovine DNA over the 40 amplification cycles. However, similar to the findings for TaqMan MGB real-time PCR, variability was noted at concentrations below 0.05 ng. Additionally, the signals detected at 0.05 and $0.005 \mathrm{ng}$ of DNA were probably from primer dimers, which were identified by their lower melting temperatures. Therefore, we concluded that our SYBR Green real-time PCR method can be considered reliable only at $0.5 \mathrm{ng}$ and higher concentrations.

\section{Validation of our TaqMan MGB Real-Time PCR Assay}

To validate our assay for practical application, we tested various food products for the presence of milk. We extracted DNA from 42 commercial food products of different brands and with different label declarations of ingredients differing with respect to the presence or absence of milk. The DNA concentrations were measured by UV absorption spectrophotometry, and the amplification Ct values were determined using our realtime PCR protocol (Table 1). Of the 42 tested food products, bovine DNA was detected in all 29 products labeled as containing and may contain cow milk, whereas we failed to obtain a signal from the other 13 products labeled does not contain and may contain cow milk. Our results qualitatively corresponded with the declarations of containing and does not contain cow milk on food packaging. However, 3 products showed positive signals of 7 products labeled may contain cow milk.

\section{DISCUSSION}

Here, we describe a DNA-based method for the indirect detection of milk allergens in food, in which the target molecule is a specific DNA sequence that is

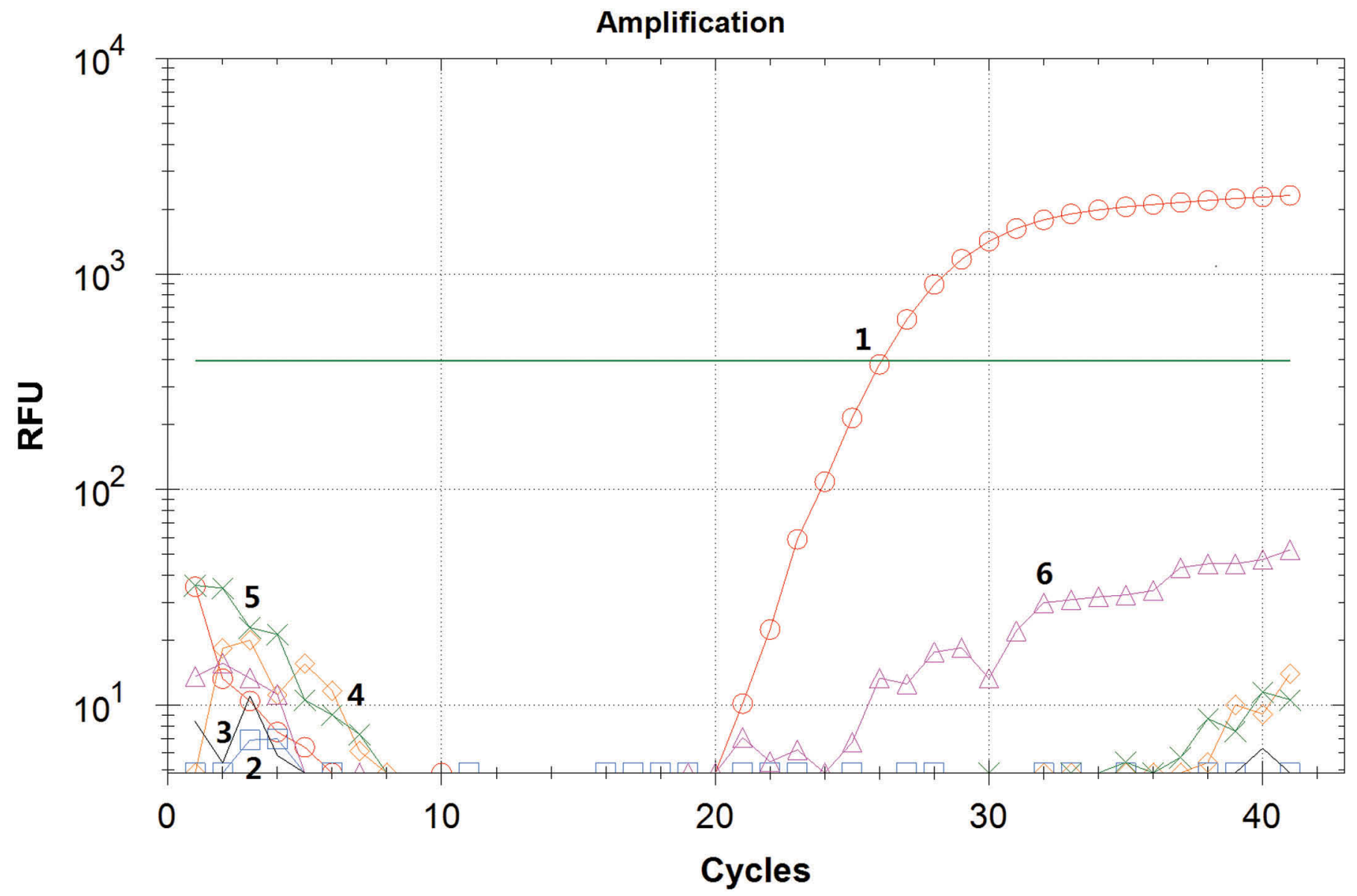

Figure 2. The specificity of the TaqMan minor groove binder (Genecore, NCBI: AF249896.1, 806-820) real-time PCR method. Curves 1-6: cow milk (circle), goat milk (square), soybean milk (straight line), peanut (diamond), hazelnut (cross), and Atlantic salmon (triangle), respectively. RFU = relative fluorescence units. Color version available online. 
detected by TaqMan MGB real-time PCR (Iniesto et al., 2013). Compared with methods that rely on protein detection, DNA-based technologies have distinct advantages, including greater thermostability and the ability to analyze highly processed food products. In addition, these techniques are cheaper, faster, and more sensitive (Herrero et al., 2012). In DNA-based methods, DNA oligonucleotides are used to hybridize to target DNA molecules, whereas protein-based detection methods are much more expensive (Espineira et al., 2010). Moreover, the use of real-time PCR allows for monitoring during the course of the assay, saving time compared with assays that require gel-based visualization or the use of secondary antibodies for visualization. The total time required for DNA extraction and detection by real-time PCR was approximately $3 \mathrm{~h}$, which is much faster than antigen detection by ELISA.

The MGB probes have greater sequence specificity due to their shorter length (Akkutay et al., 2014). Furthermore, the use of higher melting temperatures increases the stability of the hybridization, resulting in higher sensitivity (Kutyavin et al., 2000). We tested samples from 6 different food sources and a positive signal was detected only when using DNA extracted from cow milk, whereas no signal was detected from DNA extracted from other sources (goat milk, soybean milk, peanuts, hazelnuts, or salmon). In our study, a TaqMan MGB real-time PCR method was developed for the rapid and accurate detection of cow milk DNA and to overcome the false-positive signals that are common in SYBR Green real-time PCR-based assays caused by the formation of primer dimers, which may form when testing trace quantities of DNA. We were able to consistently detect $0.05 \mathrm{ng}$ of DNA, which corresponds to $2.5 \mathrm{mg}$ of starting material (from which the DNA was extracted). In a previous study, Köppel et al. (2009) used real-time PCR to detect the presence of 8 different food allergens; for most of the allergens (except for eggs and milk), $10 \mathrm{mg}$ or more of input material was required for detection. Similarly, Scaravelli et al.

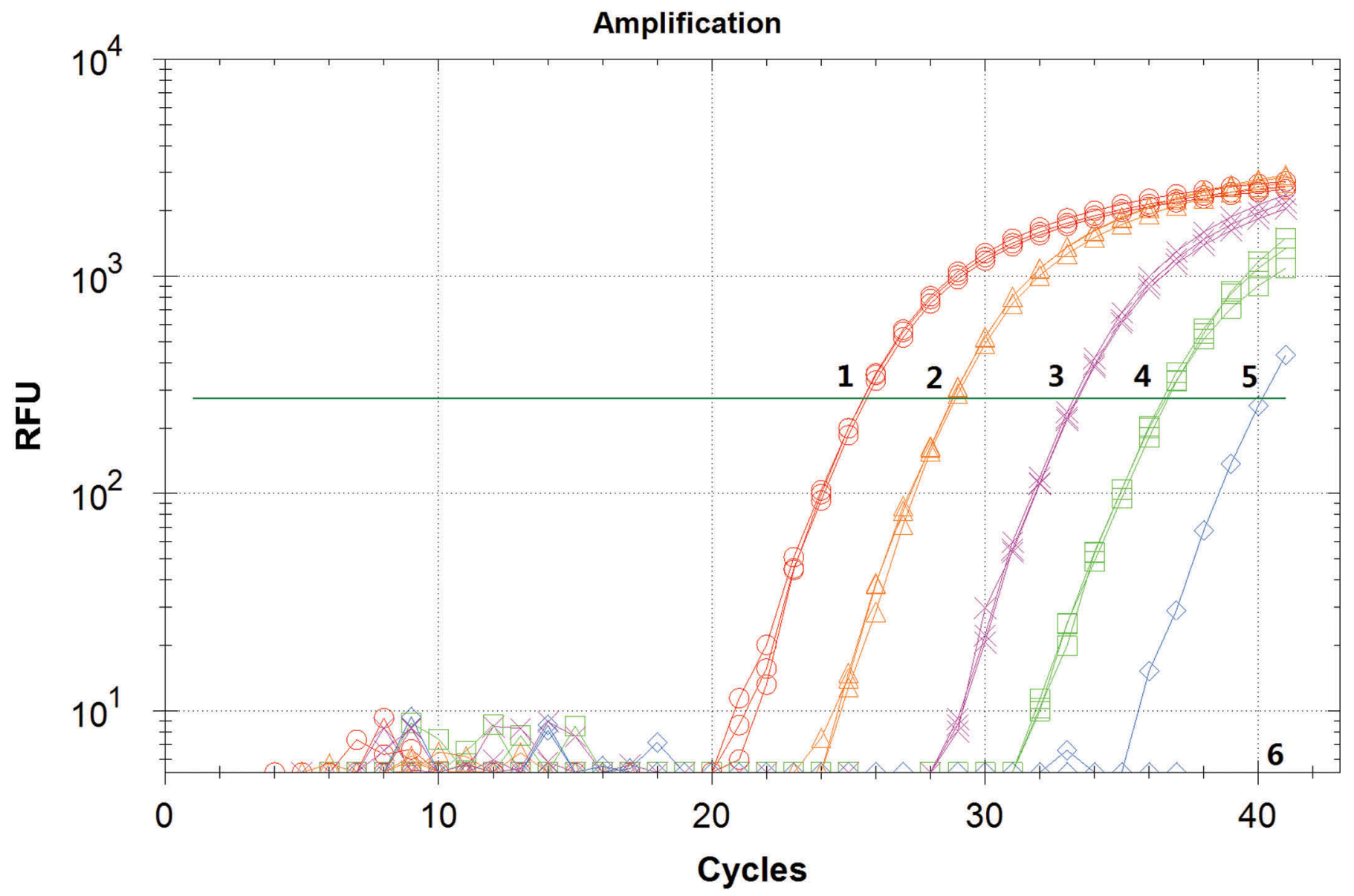

Figure 3. Amplification of $\alpha$-LA gene fragment from cow milk DNA. Curves 1-6: 50 (circle), 5 (triangle), 0.5 (cross), 0.05 (square), 0.005 (diamond), and 0 (straight line) ng of DNA, respectively. RFU = relative fluorescence units. Color version available online. 
(2007) developed a method for real-time PCR detection of peanuts in food products. This assay was highly sensitive, as it could detect as little as $2.5 \mathrm{pg}$ of DNA; however, the signal detection at these low amounts of DNA was inconsistent. López-Calleja et al. (2007b) used a PCR-based method to detect the presence of sheep and goat cheese in foods. In the same study, the authors described a real-time PCR method for the quantitation of the relative amounts of cow and ewe milk components in mixtures. For this assay, 5 to 100 $\mathrm{mg}$ of starting material was required (López-Calleja et al., 2007a).

In the present study, we established a real-time PCR TaqMan MGB-based method to detect cow milk DNA in food items. We tested 6 kinds of candies, 17 kinds of biscuits, 7 kinds of chocolate, and 12 kinds of drinks. These samples represent 42 common goods that may contain milk ingredients and are representative of the diversity of goods that could be tested. The food items we chose are processed differently during manufacture and contain a variety of additional ingredients. The DNA extracts produced contained various unique impurities. The same amount of total DNA was used as the input in all reactions, and our results were $100 \%$ consistent with the absence or presence of milk, as indicated on the food label. These results demonstrate that the ability to detect bovine DNA using our TaqMan MGB real-time PCR method was not affected by either the other ingredients, such as sugar and fat, in the foods or the processing procedures, such as baking (Monaci et al., 2011). Therefore, this method can be widely used for the detection of milk allergens in different types of food.

In the current study, we developed a TaqMan MGB real-time PCR-based method that can be used to detect the presence of $\alpha$-LA. Our data demonstrated that this method is specific, sensitive, robust, and reproducible. The practical use of our assay was validated by testing 42 commercial food items for the presence of milk.

\section{Amplification}

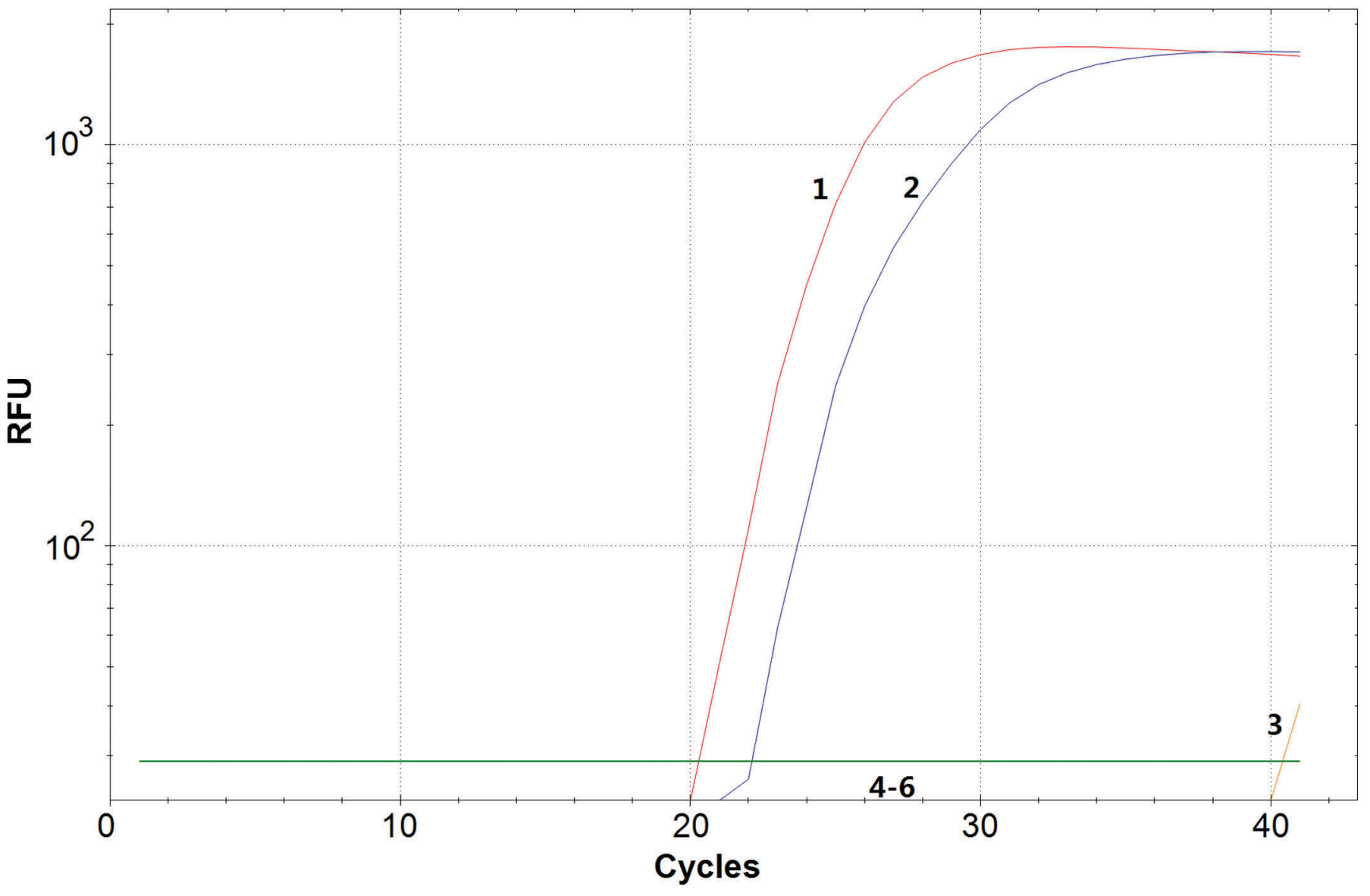

Figure 4. Specificity of SYBR Green (Toyobo, Osaka, Japan) real-time PCR. Curves: $1=$ cow milk; $2=$ goat milk; $3=$ soybean milk; $4=$ peanuts; 5 = hazelnut; $6=$ Atlantic salmon. RFU $=$ relative fluorescence units. Color version available online. 
Table 1. Analysis of DNA extracts from labeled commercial food products by using the TaqMan minor groove binder (Genecore, NCBI: AF249896.1, 806-820) real-time PCR assay

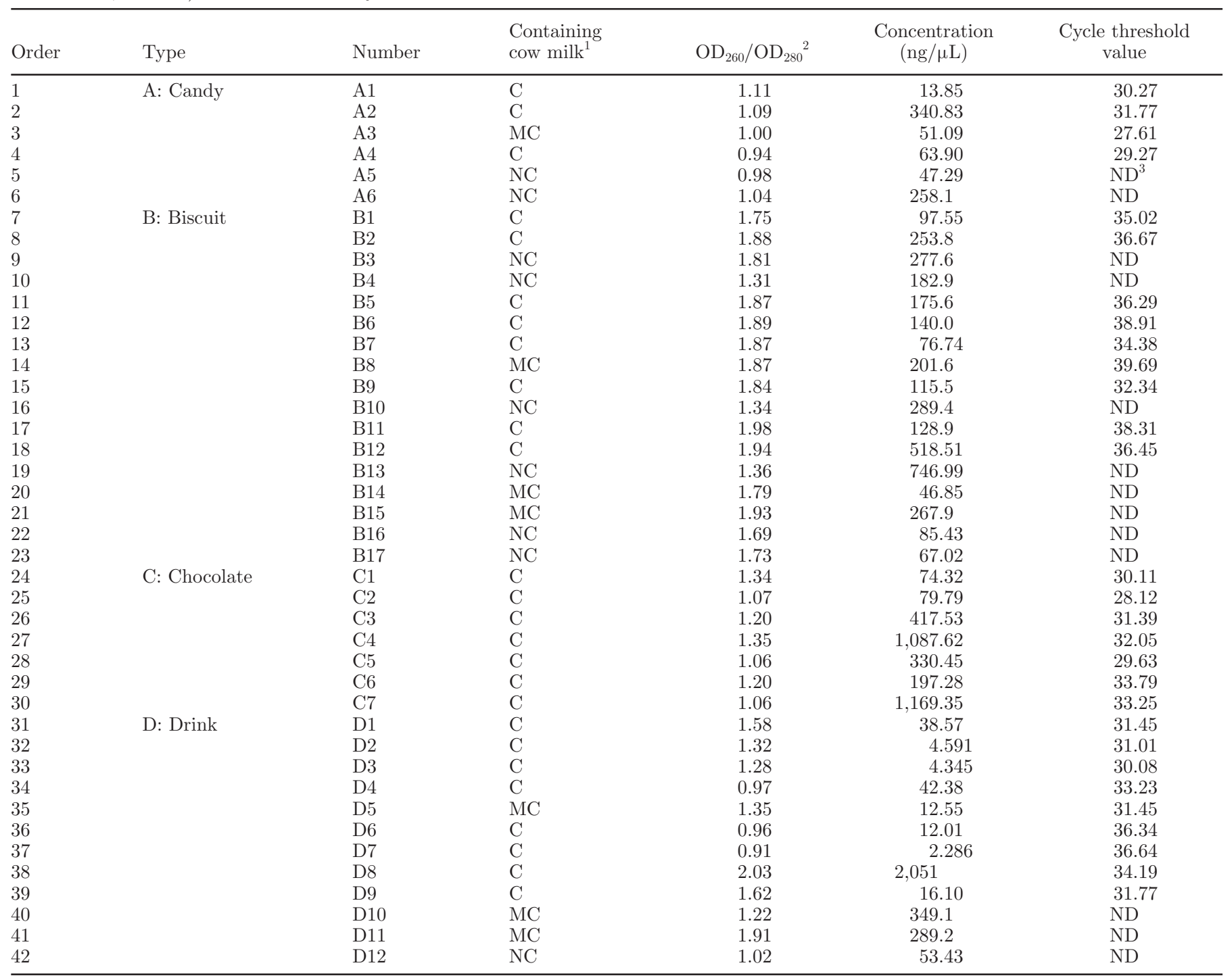

${ }^{1} \mathrm{C}=$ containing; $\mathrm{MC}=$ may contain; $\mathrm{NC}=$ does not contain.

${ }^{2}$ Ratio of optical density at 260 and $280 \mathrm{~nm}$.

${ }^{3} \mathrm{ND}=$ not detected.

\section{ACKNOWLEDGMENTS}

This study was supported by a grant from the National Natural Science Foundation of China (Beijing; No. 31201306), the project of the Food Science Discipline Construction of Shanghai University (School of Life Science, Shanghai, China), and a grant from the National Key Technology Support Program of China (Beijing; No. 2013BAD12B06).

\section{REFERENCES}

Akkutay, A. Z., N. Osterrieder, A. Damiani, B. K. Tischer, K. Borchers, and F. Alkan. 2014. Prevalence of equine gammaherpesviruses on breeding farms in Turkey and development of a TaqMan MGB real-time PCR to detect equine herpesvirus 5 (EHV-5). Arch. Virol. 159:2989-2995.

Bock, S. A. 1987. Prospective appraisal of complaints of adverse reactions to foods in children during the first 3 years of life. Pediatrics 79:683-688.

Boyce, J. A., A. Assa'ad, A. W. Burks, S. M. Jones, H. A. Sampson, R. A. Wood, M. Plaut, S. F. Cooper, M. J. Fenton, S. H. Arshad, S. L. Bahna, L. A. Beck, C. Byrd-Bredbenner, C. A. Camargo Jr., L. Eichenfield, G. T. Furuta, J. M. Hanifin, C. Jones, M. Kraft, B. D. Levy, P. Lieberman, S. Luccioli, K. M. McCall, L. C. Schneider, R. A. Simon, F. E. Simons, S. J. Teach, B. P. Yawn, and J. M. Schwaninger. 2011. Guidelines for the diagnosis and management of food allergy in the United States: Summary of the NIAID-sponsored expert panel report. Nutr. Res. 31:61-75.

Businco, L., P. Falconieri, P. Giampietro, and B. Bellioni. 1995. Food allergy and asthma. Pediatr. Pulmonol. Suppl. 11:59-60. 
Docena, G., P. Rozenfeld, R. Fernandez, and C. A. Fossati. 2002. Evaluation of the residual antigenicity and allergenicity of cow's milk substitutes by in vitro tests. Allergy 57:83-91.

Eissa, S., C. Tlili, L. L'Hocine, and M. Zourob. 2012. Electrochemical immunosensor for the milk allergen beta-lactoglobulin based on electrografting of organic film on graphene modified screen-printed carbon electrodes. Biosens. Bioelectron. 38:308-313.

Espineira, M., B. Herrero, J. M. Vieites, and F. J. Santaclara. 2010 Validation of end-point and real-time PCR methods for the rapid detection of soy allergen in processed products. Food Addit. Contam. Part A Chem. Anal. Control Expo. Risk Assess. 27:426-432.

Herrero, B., J. M. Vieites, and M. Espineira. 2012. Fast real-time PCR for the detection of crustacean allergen in foods. J. Agric. Food Chem. 60:1893-1897.

Høst, A., and S. Halken. 1990. A prospective study of cow milk allergy in Danish infants during the first 3 years of life. Clinical course in relation to clinical and immunological type of hypersensitivity reaction. Allergy 45:587-596.

Iniesto, E., A. Jimenez, N. Prieto, B. Cabanillas, C. Burbano, M. M. Pedrosa, J. Rodriguez, M. Muzquiz, J. F. Crespo, C. Cuadrado, and R. Linacero. 2013. Real Time PCR to detect hazelnut allergen coding sequences in processed foods. Food Chem. 138:1976-1981.

Johnson, P. E., I. Van der Plancken, A. Balasa, F. A. Husband, T. Grauwet, M. Hendrickx, D. Knorr, E. N. Mills, and A. R. Mackie. 2010. High pressure, thermal and pulsed electric-field-induced structural changes in selected food allergens. Mol. Nutr. Food Res. $54: 1701-1710$

Khuda, S., A. Slate, M. Pereira, F. Al-Taher, L. Jackson, C. DiazAmigo, E. C. Bigley 3rd, T. Whitaker, and K. M. Williams. 2012. Effect of processing on recovery and variability associated with immunochemical analytical methods for multiple allergens in a single matrix: sugar cookies. J. Agric. Food Chem. 60:4195-4203.

Koch, P., G. F. Schappi, R. E. Poms, B. Wuthrich, E. Anklam, and R. Battaglia. 2003. Comparison of commercially available ELISA kits with human sera-based detection methods for peanut allergens in foods. Food Addit. Contam. 20:797-803.

Köppel, R., V. Dvorak, F. Zimmerli, A. Breitenmoser, A. Eugster, and H.-U. Waiblinger. 2009. Two tetraplex real-time PCR for the detection and quantification of DNA from eight allergens in food. Eur. Food Res. Technol. 230:367-374.

Kutyavin, I. V., I. A. Afonina, A. Mills, V. V. Gorn, E. A. Lukhtanov, E. S. Belousov, M. J. Singer, D. K. Walburger, S. G. Lokhov, A. A. Gall, R. Dempcy, M. W. Reed, R. B. Meyer, and J. Hedgpeth. 2000. 3'-minor groove binder-DNA probes increase sequence specificity at PCR extension temperatures. Nucleic Acids Res. $28: 655-661$.

López-Calleja, I., I. González, V. Fajardo, I. Martín, P. E. Hernández, T. García, and R. Martín. 2007a. Real-time TaqMan PCR for quantitative detection of cows' milk in ewes' milk mixtures. Int. Dairy J. 17:729-736.

López-Calleja, I. M., S. de la Cruz, N. Pegels, I. González, T. García, and R. Martín. 2013. Development of a real time PCR assay for detection of allergenic trace amounts of peanut (Arachis hypogaea) in processed foods. Food Contr. 30:480-490.

López-Calleja, I. M., I. González, V. Fajardo, P. E. Hernández, T. García, and R. Martín. 2007b. Application of an indirect ELISA and a PCR technique for detection of cows' milk in sheep's and goats' milk cheeses. Int. Dairy J. 17:87-93.

Monaci, L., M. Brohee, V. Tregoat, and A. van Hengel. 2011. Influence of baking time and matrix effects on the detection of milk allergens in cookie model food system by ELISA. Food Chem. 127:669-675.
Pan, D. D., Z. Wu, J. Liu, X. Y. Cao, and X. Q. Zeng. 2013. Immunomodulatory and hypoallergenic properties of milk protein hydrolysates in ICR mice. J. Dairy Sci. 96:4958-4964.

Posada-Ayala, M., G. Alvarez-Llamas, A. S. Maroto, X. Maes, E. Munoz-Garcia, M. Villalba, R. Rodriguez, M. Perez-Gordo, F. Vivanco, C. Pastor-Vargas, and J. Cuesta-Herranz. 2015. Novel liquid chromatography-mass spectrometry method for sensitive determination of the mustard allergen Sin a 1 in food. Food Chem. 183:58-63.

Qing-jin, X., D. Zhi-rui, Z. Wen-ju, and C. Qin. 2012. PCR method for the detection of allergen in milk. Sci. Technol. Food Ind. 6:104-107.

Reguant, C., and A. Bordons. 2003. Typification of Oenococcus oeni strains by multiplex RAPD-PCR and study of population dynamics during malolactic fermentation. J. Appl. Microbiol. 95:344-353.

Rodriguez-Lazaro, D., N. Cook, and M. Hernandez. 2013. Real-time PCR in food science: PCR diagnostics. Curr. Issues Mol. Biol. 15:39-44.

Rodriguez-Lazaro, D., and M. Hernandez. 2013. Real-time PCR in food science: Introduction. Curr. Issues Mol. Biol. 15:25-38.

Ruiz-Valdepeñas Montiel, V.. S. Campuzano, A. Pellicano, R. M. Torrente-Rodriguez, A. J. Reviejo, M. S. Cosio, and J. M. Pingarron. 2015. Sensitive and selective magnetoimmunosensing platform for determination of the food allergen Ara h 1. Anal. Chim. Acta $880: 52-59$

Saarinen, K. M., A. S. Pelkonen, M. J. Makela, and E. Savilahti. 2005. Clinical course and prognosis of cow's milk allergy are dependent on milk-specific IgE status. J. Allergy Clin. Immunol. 116:869-875.

Scaravelli, E., M. Brohée, R. Marchelli, and A. J. van Hengel. 2007. Development of three real-time PCR assays to detect peanut allergen residue in processed food products. Eur. Food Res. Technol. 227:857-869.

Scaravelli, E., M. Brohee, R. Marchelli, and A. J. van Hengel. 2009. The effect of heat treatment on the detection of peanut allergens as determined by ELISA and real-time PCR. Anal. Bioanal. Chem. 395:127-137.

Schrander, J. J., J. P. van den Bogart, P. P. Forget, C. T. Schrander-Stumpel, R. H. Kuijten, and A. D. Kester. 1993. Cow's milk protein intolerance in infants under 1 year of age: a prospective epidemiological study. Eur. J. Pediatr. 152:640-644

Song, F., Y. Zhou, Y. S. Li, X. M. Meng, X. Y. Meng, J. Q. Liu, S Y. Lu, H. L. Ren, P. Hu, Z. S. Liu, Y. Y. Zhang, and J. H. Zhang. 2014. A rapid immunomagnetic beads-based immunoassay for the detection of beta-casein in bovine milk. Food Chem. 158:445-448.

Stephan, O., and S. Vieths. 2004. Development of a real-time PCR and a sandwich ELISA for detection of potentially allergenic trace amounts of peanut (Arachis hypogaea) in processed foods. J. Agric. Food Chem. 52:3754-3760.

Wijesinha-Bettoni, R., C. Gao, J. A. Jenkins, A. R. Mackie, P. J. Wilde, E. N. Mills, and L. J. Smith. 2007. Heat treatment of bovine alpha-lactalbumin results in partially folded, disulfide bond shuffled states with enhanced surface activity. Biochemistry 46:9774-9784.

Xian, X., C. Qin, Y. Ke-lan, and H. Yi-Yi. 2008. Application of PCR in analyzing farm sources. Food Sci. Technol. (Campinas.) 33:258261.

Zhang, W. J., Q. Cai, X. Guan, and Q. Chen. 2015. Detection of peanut (Arachis hypogaea) allergen by real-time PCR method with internal amplification control. Food Chem. 174:547-552. 